\title{
HET BEMEDICINEEREN VAN EEN DORP IN HET LANDSCHAP BOLAANG MONGONDOW (NOORD CELEBES).
}

\author{
DOOR \\ W. DUNNEBIER.
}

Inleiding.

Het hier onder volgende is een beschrijving van een plechtigheid, die vroeger geregeld werd gevierd in de dorpen van Bolaang Mongondow, maar in de latere jaren van ons verblijf aldaar veel minder in eere werd gehouden, en op den duur w. s. wel zal verdwijnen, zooals ook met andere voorvaderlijke gewoonten het geval is.

Deze godsdienstige handeling, - in het Bolaang Mongondowsch monibi en ook mongoendam ko lipoe' : een dorp bemedicineeren, genaamd, - hebben ook de Heeren Wilken en Schwarz vermeld en toegelicht in de Mededeelingen vanwege het Nederlandsche Zendelinggenootschap, deel XI (1867), blz. 271 v.v.

Het hier vertelde werd mij vele jaren geleden medegedeeld door een rasechten Mongondower met veel gevoel voor zijn eigen taal.

$\mathrm{Er}$ is naar een zooveel mogelijk letterlijke vertaling gestreefd, terwijl eenige woorden van een aanteekening werden voorzien. Het in deze aanteekeningen meermalen voorkomende $\S$-teeken wil zeggen: paragraaf van de Spraakkunst van het Bolaang Mongondowsch, opgenomen in de Bijdragen van het Koninklijk Instituut voor de Taal-, Land- en Volkenkunde van Nederlandsch-Indië, deel 85 (blz. 297468, 524 -621) en deel 86 (blz. 42-177).

$\mathrm{Na}$ dit opstel volgen eenige zangen, die met het bemedicineeren van een dorp geen verband houden, daarmee alleen dit gemeen hebben, dat zij een stukje Bolaang Mongondowsche taal vertegenwoordigen.

D1. 104. 


\section{MONIBI ${ }^{1}$ ).}

A pa ko moena-monik, bajongan i intau inta moena nobiag ko lopa' im Bolaang Mongondow naa, dia'-pa-bi' notantoe' im pinogoetoenan, sing kon dodai in toea dia'-pa kolipoe ${ }^{2}$ ), dia'-pa kobaloi ${ }^{2}$ ) inta kododotan ${ }^{3}$ ), dia'-pa kodatoe bo dia'-pa kobobato inta pokidongogan ${ }^{4}$ ).

Kon dodai in toea ojoeon $\mathrm{i}$ intau kohongian ${ }^{5}$ ) tobatoe', tangoinja ki abo' i Sadohe' ${ }^{6}$ ). Bai ng ki abo' i Sadohe' bo dongka nobali' in sigi (monibi).

Kon toengkoel-pa i abo' i Sadohe' ojoeon i intau toeang i lipoe' tobatoe', tangoinja ki Paloko' 7 ). Ki Paloko' naa intau inta mopandoi bo mobarani, sia im pinomia goehangēea i lipoé.

Binaja'an-makow in singgai-mai tobatoe', norai ing ki Paloko', kainia: „Naonda-pa im pososipoenkoe kom bajongan i intau minta, inta positaboed naa?'. Kon toea minaja'don in sia nogoïni' kom bajongan i intau inta positaboed toea, kainia: „Bajongan-naton, komintan-pa mojosipoen si ojoeon im bakidon”. Kon toea, jo noboeka'-don kom

1) monibi, een dorp bemedicineeren, gr.w. sibi. Het wil me voorkomen dat sibi het oorspronkelijke woord voor dorpstempeltje zal zijn geweest, hoewel men later daarvoor sigi bezigde. In Med. XI, bl. 272 (1867) wordt gezegd, dat wanneer dit offer in Bolaang plaats had, er twee hutjes werden opgericht, een sigi en een sibi. De sigi was bestemd voor de geesten der voorouders van het volk en de sibi voor die van het Radja-geslacht. (Ik acht het zeer w.s., dat het woord sigi zijn ontstaan dankt aan masigi, wat men ook hoort voor 't heidensche dorpstempeltje, een verbastering van het Javaansche mesigit?). Uit het hier gegeven Mong. verhaal blijkt, dat het tempeltje voor de vorstelijke zielen, opgericht op het erf van het dorpshoofd, karawan wordt genoemd.

Hoe sigi moeielijk het oudste woord voor zoo'n dorpstempeltje kan zijn geweest, blijkt m.i. hieruit dat „Monigi” niet gebruikelijk is.

2) kolipoe'.... kobaloi; ko- heeft hier bezitaanduidende beteekenis, zie $\S 116$, onder le van de Spraakk. van het Bol. Mong. (Bijdr. Kon. Inst. v. T., L. en V., deel 85 en 86 ).

3) kododotan, waar wordt verbleven, waar men zich ophoudt; mododot, stil zijn, rustig, geen bewegingen maken.

4) pokidongogan, naar wien men luistert, wien men gehoorzaamt. Voor poki$-a n$, zie $\S 72$ v. gen. Spr.k..

5) kohongian, adelstand. Volgens de overlevering heeft de in dit verhaal genoemde Sadohe' (Tadohe') niet alleen het monibi ingesteld, maar ook de zes standen: Radja-, Kohongian-, Simpal-, Nonow-, Tahig- en Joboeat-stand.

6) Sadohe' of Tadohe' (de s- en t- wisselen heel gemakkelijk in Bol. M.) wordt in dit verhaal de ,stamvader" of de ,oorsprong” van de vorsten (van Bol. M.) genoemd; hij moet iemand van meer dan gewone beteekenis zijn geweest.

7) Paloko', is een beroemde voorvader van den Simpal-stand (vooraanstaande burgers); hij was een oudere tijdgenoot van Tadohe'. 
bakid, kainia: „Bajongan-monimoe komintan-pa mosipoen-mai sing kita moniat-pa momia kom binoboi ${ }^{8}$ ) mobagoe".

Naonda i nobali'-don im binoboi toea, jo minaja' bidon ing ki Paloko' toea noboei nokiöini' bo nokisipoen kom bajongan i intau tongo doea, kai ng kojowēā: „Baja'-don tokopogoeman ${ }^{9}$ ) kom bajongan-don $\mathrm{i}$ intau inta mojodoengkoelmoe, kamakow: naaia aindon nobali' im binoboi; komintan-pa mojosipoen-mai ing kita komintan, si a pa motoenggoe ${ }^{10}$ ) kon dimoekoed i moena-monik, si a pa poïgoeman kom barakat kom binoboi mobagoe".

Nion in dinoedoeian in sinoemi ${ }^{11}$ ) magi' inaa ; oemoeran mongoendam ${ }^{12}$ ) ko lipoe', poigoeman barakat kon datoe moena bo kom boki' moena: kong koboeían im bobiagon, kobiagan-pa i intau bo pomoeka'an-pa i ridjiki. Monibi naa pomiaan tongo tāōng komintan.

Ko moena-monik, toengkoel a pa doenia motomba' ${ }^{13}$ ), dodai in toea motojoe' i mangkoebi ${ }^{14}$ ), tango-tangoian: loekad i lipoe', inta mopoangoi im bodito ko lipoe'. Ojoeon ing kobangonan-monik, sio' kantong ${ }^{15}$ ) toemongobatoe' ing kaanon i mangkoebi' toea. Kobangonan-monik, dongka koelit in sio' toea ing karangonea kon tondok mongo toeod. Aka ojoeon in tomba' inta na'toea, jo mojosingog-don kom pononibi bo monibi-don.

Ojoeon doman, aka dia'-don pomoeka'an i ridjiki, dia'-don pomoengaian i ajop, dia'-don kotoloeboe'an im pomomoelaan, mongo dia'don kobiagan im bobiagon, jo mojosingog bidon kom pononibi bo monibi-don.

Aka lipoe' kojopoe'an-don, mangalenja: motojoe'-don i intau i

s) binoboi, het op een rij geschaarde, geplaatste; in hooge of priestertaal: dorp; boboi, rij, moboboi, op een rij met het gezicht naar één kant.

9) tokopogoeman, gr.w. oeman; pogoeman, zeg het; tokopogoeman, zeg het allen. Voor toko- zie $\$ 133$.

10) motoenggoe, eerbiedig en feestelijk ontvangen van geesten met een offermaaltijd, hiertoe noodigen. We hebben hier met het Maleische toenggoe, waken, wachten, te doen, maar het is hier hooge of deftige taal geworden.

11) sinoemi, gr.w. toemi, de achtergelatenen, de nakomelingen, 't nageslacht; toemi, achter.

12) mongoendam, bemedicineeren, d.w.z. den geesten offeren om zieken te genezen, onheil af te wenden, het dorp krachtig te maken enz.; het is ook gebruikelijk geworden voor de Europeesche behandeling van zieken.

$\left.{ }^{13}\right)$ tomba', onheil, ramp, ontstellende dingen; $m o t o m b a^{\prime}$, onheilbrengend, schrikaanjagend.

14) mangkoebi', boschgeest(en), onderdanen van Angkoebi', die op de menschen worden losgelaten, als deze niet op tijd offeren, om hen zoo aan hun plichten te herinneren. Ook als men „verboden” dingen doet, komen de mangkoebi's dit vergelden.

15) kantong, groot, vet varken. 
matoi mongo motakit, mongo mododoejoe, jo mojosingog bidon kom pononibi bo monibi-don (mongoendam-don ko lipoe').

Aka aindon moniat monibi toea, jo mobakid im bajongan $\mathrm{i}$ itoi, goehangēà i lipoe' taki-takin im bobato, monantoe' kom pononibi bo mojosingog kom pototaloei kon sio' bo bembe'; bo dolom doman inta toea monantoe'-don kong goehangēā inta monoetoeng ing kamanja, mololaboeng-monag kon singgai sinantoe' toea. Aka dia' mobojobojo' $\left.^{16}\right)$, kon toea maja'-don ing goehangēa inta sinantoe' toea monoetoeng kong kamanja toea. Moïbaja'-mai im popod i lipoe' toea, jo toeba'anēa ing kamanja toea bo mosilon; mopaloet-makow toea moningkod in sia kom boeta' bo mosingog, kainia ; ,Ompoe' toemolan, tonga' poigoemon barakat, poigoemon do'a kon dimoekoed i mogogoejang bo kon dimoekoed in datoe moena: kong kobiagan-pa i intau, kong koboei'an-pa im bobiagon, kong koroembaan-pa im pomomoelaan, sing kami i a pa-bi' motoenggoe ko imonimoe; ridjiki in tonga'-pa popomoera-mai, maja'-makow i na'-pa pomoetoeng ${ }^{17}$ )".

Kon singgai doman inta toea, bajongan $\mathrm{i}$ intau komintan-don mopolitoe $^{\prime 18}$ ) kom balo-baloianēā. Popolitoe'an toea, kede' im pọlapag, bambe'on ko olabat, dega' tongo jopa-mai i langgo'nja; liboenja in dininding in sikajoe kon dampig im bonoenja; kon dampig i likoedēa liboeon in toeboe' in daoen ing koito'. Kom bonoe im polapag toea, pogoekatan kom pomama' bo tabakoe' bo golantoeng. Lolaboeng dolodolom bongkoegon ing golantoeng inta toea, bo silonan bo kapoion ${ }^{19}$ ) bo insingogan, kainia: „Litoe' ko nion ing ki laki ki Dondo, sing kami

16) mobojo-bojo', bezorgd, angstig, bekommerd vanwege ziekte en onheilspellende dingen als bijv. vogelgeschrei, kwade droomen, en dan dus verhinderd om iets wat men van plan was uit te voeren; bojo' $i$ adi ${ }^{\prime}$ : kinderziekten (stuipen, mazelen); adi' mobojo': ziek kind.

17) pomoetoeng, gr.w. boetoeng, iets dat men plotseling, onverwacht, krijgt; het kan zoowel een vuiltje in 't oog zijn, als de onverhoopte vervulling van een wensch, het gelukken van iets wat men onderneemt. $i n a^{\prime}$-pa pomoetoeng: dat het dan moge zijn gelijk gehoopt wordt. (-pa heeft hier wenschende kracht, of liever: stempelt het verzoek tot een smeekbede).

18) mopolito $e^{\prime}$, letterlijk: zetten, iemand of iets in zittende houding brengen (litoe' ${ }^{\prime}$ zitten), maar hier beteekent het: maatregelen treffen door het aanbrengen van kleine offerstellages om zoo de geesten te noodigen tot den offermaaltijd, hun te verzoeken plaats te nemen aan den feestdisch.

19) kapoion, geesten uitnoodigen; kapoi, mokapoi: onder veel gezwaai met armen en doeken de geesten aanroepen, ze noodigen tot den maaltijd, ze verzoeken de zieken te verlaten en zich te goed te doen aan de klaar gezette spijzen, en dan na den maaltijd ze weer verzoeken ergens anders naar toe te gaan; kokapoi: doek waarmee wordt gezwaaid, uitgenoodigd; mokokapoi, degeen die uitnoodigt, een helper of helpster van den priester(es). Een mokokapoi is nog geen bolian (priester), die bezeten raakt. Mokapoi beteekent ook wuiven. 
i a pa-bi' motoenggoe ko imonimoe: kong kobiagan-pa i intau, koboei'an-pa im bobiagon, ridjiki in tonga'-pa popomoera, sing kami i a pa-bi' motoenggoe bo motoeloeng ko imonimoe dete laki”.

Naaia in tangoi in takit minta, inta politoe'on mongo oendaman : ki inta kon sigi, nion ki Angkoebi ${ }^{20}$ ); ki inta kong karawan, nion asal ${ }^{21}$ ) datoe, ki Sadohe'; ki laki ki Doengkoel; dimoekoed ing Kobo'; ki laki ki Dondo; ki laki ki Simbonan; ki Bokolow, ki inta ko oeloean in toebig; ki Beken; ki baai ki Dodongkilat (Dongankilat); astal ki Dodal ; asal ki Simbala.

Ki Angkoebi' im politoe'on kon sigi. Dimoekoed i abo' i Sadohe' im politoe'on kong karawan. Bo kapoion lolaboeng dolo-dolom, kon dalom in toloe gobii toea. Kon dodai in toea lipoe' im potonon: dia' mobali' ponomba'an (ponogooelitan) ${ }^{22}$ ), dia' pojogiowan, dia' mobali' koangoian mongo kotaliban i intaut tongo lipoe'an i lipoe'.

Sigi, nion kede' i laig, patokon kom potojoeakan i lipoe'; liboenja in dindingon in daoen ing koito' songka'an; kom bonoenja in dindingon in sikajoe, popoaip kon daoen ing koïto' toea. Kom bonoenja toea im popolitoe'an i oloenan dojowa, lolaki bo bobai. Ki inta lolaki in solana'an, lamboengan bo lensoan. Jo ki inta bobai im bintolan, lamboengan, poejoengan, bobolan bo patedaan. Nion in tango-tangoian : toelada. Kon dalom in toloe gobii, pomoeloi in dolom dia' piongan kon toga' bo tantoe' loekadan i intau im bonoe in sigi toea.

Karawan toea kede' doman i laig, patokon kon dolaag im bobato; liboeon doman in daoen ing koito' bo sikajoe, bo pomiaan doman kon toelada lolaki bo bobai bo popolitoe'-makow na' toelada doman kom bonoe in sigi. Kon tajowon in toelada toea oekaton im pakeang. Toelada inta kom bonoe ing karawan naa, nion im popoïbarat ki abo' i Sadohe' bo ki boea'nja. Toelada inta kom bonoe in sigi, popoïbarat ki Angkoebi' bo ki boeloinja.

Baja'an-makow in toloe gobii, bajongan $\mathrm{i}$ intau komintan mosipoen kom bonoe i lipoe'. Bajongan i intau, inta nopolitoe', komintan momia ko ngongoendaman kon dolaagēa, pogoekatan kong kaanon, inta tokooekaton im bajongan i intau, naonda i aindon mokapoi. Dolo-dolommonik kom pokokapoi toea, bajongan i intau komintan modoengoe'. Aindon mololaboeng, komintan-don mamangoi mogoekat ing kaanon

20) Angkoebi', het opperhoofd der mangkoebi's. Zie onder 14.

21) asal, Arab. oorsprong, afkomst, is hier vertaald met stamvader.

22 ) ponogooelitan, tijd waarop of plaats waar verboden woorden worden gebezigd, monogooelit: verboden woorden (togooelit) bezigen. Voor het nog slechts bij enkele woorden voorkomende praefix togo-, zie $\S 143$. 
kom polapag inta pinomia kon dolaag in tobatoe'-tobatoe'. Kon toea bajongan $\mathrm{i}$ intau komintan moponag kon dolaag mokikapoi ; bajongan im bolian komintan mojosipoen. Naonda i mopaloetdon mokapoi, jo kaanon inta kon sigi toea potaboed kon dolaag. Naonda in tomokandon, jo bajongan im bolian komintan mogalow kon takit toea, takitakin i intau mobajong, kabiton kom popod tongo pongko' bo moribatoek loeai-toeot kon sioep magi'-makow. Naonda i mopaloet-makow toea, jo mojosipoen-don im bajongan im bolian bo intau minta toea, bo molibo' kom bolian mongo sinarima in takit mongo dia'. Aka sinarima-don, jo mosingog i intau goehangēā tobatoe', moïgoem barakat, kainia : „Naaia ing kami bo a pa-bi' notoenggoe ko imonimoe, jo tonga'-pa popomoera-monimoe i ridjiki, popoboei'-pa im bobiagon bo poporoemba-pa im pomomoelaan, bo intau in tonga'-pa roto-rotonan-monik. Bai n dongka kolajoegan im bango' bo pomeloengan i manoek, bo dongka ing kita moboei mojodoengkoel bo dongka moboei motoenggoe ko imonimoe".

Kon dolom doman inta toea, bajongan im bolian komintan motajok, kon dalom in toloe mongo opat no gobii, dolom bo singgai. Mobajagmakow toea ko intoloe mongo inggopat ing gobii kom pokotajok toea, jo ojoeon dega' in toloe mongo opat-mai im bolian i maja' monabang kom balo-baloianēa, taki-takin in tokiman ${ }^{23}$ ) dega' lima mongo onommai. Ponabang toea toebig in simboejoeng. Moïbaja'-mai im balobaloianēa, jo mogama' kon daoen in dajow bo popotagom kon toebig im bango' toea bo pomisik magi'-makow kon sikoe-sikoe im baloi.

Vertaling.

EEN DORP BEMEDICINEEREN.

Toen het nog in den heel ouden tijd was, al de menschen die vroeger leefden op de hoogvlakte van dit Bolaang Mongondow, (zij hadden) heusch nog niet vastgesteld de verblijfplaatsen, want in die tijden hạd (bezat) men nog geen dorpen, bezat men nog geen huizen waarin (bestendig) kon worden gewoond, had men nog geen vorst en had men nog geen hoofden naar wie men luisterde (die men volgde, gehoorzaamde).

In dien tijd was er iemand van aanzienlijk geslacht, zijn naam was: de jonker Sadohe'. Eerst (in den tijd van) jonker Sadohe' is ingesteld het offerhuisje (het bemedicineeren van het dorp).

$\left.{ }^{23}\right)$ tokiman, helper van den priester, geen ,bezeten” priester. 
Toen het nog in den tijd was van jonker Sadohe', was er een man uit den vrijen burgerstand (Simpal), zijn naam was Paloko'. Deze Paloko' was een man die verstandig en moedig was; hij was gemaakt dorpsoudste.

Nadat voorbij was gegaan ongeveer een dag (niet lang daarna), heeft Paloko' nagedacht, hij zei: „Hoe zal ik toch bijeen krijgen alle menschen die verstrooid zijn?" Vervolgens is hij gaan roepen al de menschen die daar verstrooid waren, hij zei: „Wij allen, allemaal, moeten bij elkaar komen, want er is iets waarover vergaderd moet worden”. En daarna, toen de vergadering geopend was, zei hij : „Gij allen, allemaal, zijt hier bijeen gekomen, want wij zijn toch van plan te maken een nieuw dorp (op een rij geplaatste huizen).

Toen al gereed was dat dorp, is die Paloko' weer gegaan en heeft weder laten roepen en laten bijeenkomen al de andere menschen, zijn opdracht luidde: „Ga dan zeggen tegen al de menschen die je ontmoet, zeg: $\mathrm{Nu}$ is gereed het dorp; wij allen moeten nog eens bij elkaar komen, want (wij) wenschen natuurlijk nog uit te noodigen tot (te ontvangen met) een offermaaltijd de geesten van heel vroeger, want zooals vanzelf spreekt wenschen (we hun) te verzoeken om een zegen voor het nieuwe dorp".

Dit nu is gevolgd (in stand gehouden) door (hun) nageslacht tot op heden; geregeld wordt bemedicineerd het dorp, wordt verzocht om een zegen aan de vroegere vorsten en vroegere vorstinnen: dat veel moge worden het vee, toch gezond komen te worden (mogen groeien, leven) de menschen, en (de aarde) toch moge voortbrengen levensonderhoud (het toch een tijd worde waarin uitspruit het levensonderhoud)! Dit monibi-feest wordt gehouden één jaar één keer.

In heel oude tijden, toen de wereld natuurlijk nog erg schrikaanjagend was, in die tijden waren er veel boschgeesten, gewoonlijk genoemd: bewakers van het dorp (d.w.z. steeds oplettend of ze hun slag kunnen slaan), die verwekten onheil (ongeluk) in het dorp. Het kwam voor dat men bij het opstaan bemerkte dat van de groote vette varkens één (van de kudde, of : iederen keer één) was opgegeten door die boschgeesten. Bij het opstaan vond men dan slechts de huid van dat varken, die door hem was gehangen op de omheining of op een boomstronk. Als er gebeurden ontstellende dingen die aldus waren, dan sprak men met elkaar over de viering van het monibi-feest (over de wijze waarop het dorp begeneesmiddeld moest worden) en hield het monibi-feest.

Het gebeurt ook, als het een tijd is waarin niet meer uitspruit het 
levensonderhoud, niet meer vruchtdragen de vruchtboomen, niet meer welig tiert het gewas, of niet meer goed gezond is het vee, dan spreekt men met elkaar weer over de viering van het monibi-feest en houdt het monibi-feest.

Als het dorp opraakt (komt uit te sterven), d.w.z. als reeds veel zijn de menschen die sterven of ziek zijn, of er ellendig aan toe zijn, dan spreekt men met elkaar weer over de viering van het monibi-feest en bemedicineert het dorp.

Indien men al van plan is het monibi-feest te houden, dan vergaderen alle volwassenen, de oudsten van het dorp tezamen met de hoofden, vaststellende de wijze waarop het monibi-feest zal worden gevierd, en spreken met elkaar over de kooperij van een varken en een geit; en dien avond wordt ook aangewezen de oudste die zal ontsteken den wierook (als) de avond daalt op dien (voor het feest) vastgestelden dag. Als er niets is dat bezorgd (angstig) maakt (geen onheilspellend vogelgeschrei wordt gehoord of kwade droomen wor(len gedroomd), dan gaat de oudste, die daarvoor aangewezen is, ontsteken dien wierook. Zoodra hij aankomt bij het uiteinde van dat dorp, dan roostert hij dien wierook en biedt kalk aan (d.w.z. sirihpruimbenoodigdheden); is dat afgeloopen dan stampt hij met den hiel op den grond en spreekt, zeggende : „O goden, daal neer, moge het worden goedgevonden dat (we) verzoeken om een zegen, bidden tot de geesten der voorouders en tot de geesten van vroegere vorsten, dat toch gezond mogen worden (leven, groeien) de menschen, dat toch veel mogen worden de huisdieren, dat toch weelderig moge worden het gewas, want wij wenschen natuurlijk uit te noodigen tot den offermaaltijd ulieden; doe het levensonderhoud toch overvloedig zijn, dat waar (we) op uitgaan toch mogen verkrijgen (wat we ondernemen toch moge gelukken)".

Op dienzelfden dag alle menschen, allemaal, noodigen geesten uit tot den maaltijd in de verschillende huizen (door het aanbrengen van een kleine offerstellage, waarop een pirangdoos en tabak wordt geplaatst). Waar men de geesten wil doen plaatsnemen (en vergasten), dat is een kleine offerstellage (het kleintje van een gewone offerstellage) die wordt gehangen aan een balustrade-balk, zoo ongeveer een vadem is de lengte ervan; de omtrek ervan wordt afgeschut door een antieken doek aan den binnenkant ervan, de buitenkant ervan wordt omringd door jonge blaren van den aren-palm. Binnen in die stellage daar worden geplaatst pruimbenoodigdheden en tabak en een gong. 's Avonds en 'smorgens vroeg wordt geslagen die gong, en 
worden (den geesten) sirihpruimbenoodigdheden aangeboden en worden ze uitgenoodigd (plaats te nemen) en plechtig toegesproken, men zegt: „Neem hier plaats grootvader Dondo, want wij hebben u toch een feestelijke ontvangst bereid (om $\mathrm{u}$ eerbiedig te verzoeken) dat toch gezond komen te worden de menschen, toch veel moge worden het vee, het levensonderhoud toch overvloedig moge worden, want wij ontvangen $u$ toch feestelijk en helpen $u$ (toch ook) geëerde grootouders".

Dit zijn ce namen van de geesten, die worden uitgenoodigd plaats te nemen (aan den offermaaltijd) ofwel waaraan geofferd wordt: degeen (die wordt genoodigd) in den dorpstempel dat is Angkoebi'; degeen (die wordt genoodigd) in het offerhuisje op het erf van het dorpshoofd, dat is de (oorsprong) stamvader der vorsten, Sadohe'; (verder worden genoodigd) de voorvader Doengkoel (= de eerste); de geest van Kobo'; de voorvader Dondo; de voorvader Simbonan; Bokolow, degeen die bij den oorsprong der rivieren (verblijf houdt); Beken; grootmoeder Dodongkilat (Dongankilat); de stamvader Dodal ; de stamvader Simbala.

Angkoebi' die wordt uitgenoodigd plats te nemen (aan den offermaaltijd) in den dorpstempel. De geest van jonker Sadohe' wordt uitgenoodigd aan te zitten in het kleine tempeltje. En ze worden uitgenoodigd 's avonds en 's morgens, gedurende die drie nachten. Op dien tijd is het dorp ,onder den ban”: er mag niets worden gedaan wat onheil kan veroorzaken (verboden woorden bezigen), er mag niet worden geschreeuwd (lawaai gemaakt worden), het dorp daar mogen niet komen of voorbijgaan de menschen van andere dorpen.

De dorpstempel, deze is (zooiets als) het kleintje van een tuinhut (en) wordt geplant in het midden van het dorp; de omtrek die wordt afgeschut (omwand) met blaren van den arenpalm (die) worden opengespouwen : binnenin wordt hij afgeschut (omwand) door antieke doeken, die men laat rusten tegen die aren-palmblaren. Daar binnenin is de plaats waar worden neergezet twee kussens (die) een man en een vrouw (voorstellen). (Het kussen) dat een man (voorstelt), wordt van een broek voorzien, een kabaja aangetrokken en behootddoekt. (Het kussen) dat een vrouw (voorstelt), wordt een sarong aangedaan, een kabaja aangetrokken, van een haarwrong voorzien, een halsketting omgehangen en armbanden omgedaan. Deze (aangekleede kussens) worden gewoonlijk genoemd: poppen (beelden). Gedurende drie nachten, iederen nacht wordt niet gedoofd de harslamp 
en steeds wordt bewaakt door menschen de inhoud van den dorpstempel.

Het offerhuisje (tempeltje) voor de vorstelijke geesten is ook (zooiets als) een klein tuinhutje, het wordt geplant op het voorerf van het dorpshoofd; het wordt ook omringd met aren-palmblaren en antieke doeken, en er worden ook voor gemaakt een mannelijke en een vrouwelijke pop en die worden gezet (laat men steeds zitten) gelijk ook de poppen in den dorpstempel. Vóór die poppen worden geplaatst kleeren. De poppen, die in dit kleine offerhuisje (tempeltje) zijn, met deze stelt men voor den jonker Sadohe' en zijne gemalin. De poppen, die in den dorpstempel zijn, daarmee stelt men voor Angkoebi' en zijn vrouw.

Zijn er drie nachten voorbijgegaan, (dan) komen alle menschen, allemaal, bijeen in het dorp. Alle menschen, die geesten hebben uitgenoodigd, allen maken een offerstellage op het voorerf, waarop worden geplaatst spijzen, die allemaal worden geplaatst door alle menschen, als men al de geesten uitnoodigt. 's Morgens vroeg op dien uitnoodigingstijd, alle menschen, allemaal, koken. Als het al avond wordt, allen komen plaatsen de spijzen op de stellages, die ziin gemaakt op de voorerven van ieder. En dan gaan alle menschen, allemaal, naar beneden (dalen de trappen af) naar de voorerven en laten de geesten uitnoodigen; alle priesters (priesteressen) komen bijeen. Is afgeloopen het uitnoodigen van de geesten, dan worden de spijzen die in dien dorpstempel zijn, verspreid (uitgestrooid) over het erf. Nadat (de geesten) de handen hebben gewasschen (de uitnoodigers of mokokapoi water hebben gegoten over de handen der geesten), zetten alle priesters, allemaal, de kwaadwillige geesten (als mangkoebi's, de dienaren van de pas onthaalde geesten) achterna - vergezeld door vele menschen - , te beginnen bij het eene uiteinde van het dorp en dan hollen ze in de ruimten onder de huizen uit en ingaande heren derwaarts. Als dat afgeloopen is, dan komen bij elkaar al de priesters en al die menschen, en vraagt men den priesters of (het aangebodene goedgunstig) is ontvangen door de geesten of niet. Indien het goedgunstig is aangenomen, dan neemt een oudste het woord, zegen afsmeekende, hij zegt: „Nu hebben wij ulieden toch met de noodige eerbied (en spijzen) ontvangen, moge (nu) toch ook door $\mathrm{u}$ overvloedig worden gemaakt de levensmiddelen, doe toch veel worden het vee (huisdieren) en doe toch welig groeien het gewas, en de menschen (vooral de zieken) dat die toch sterk mogen worden. E.erst als zullen komen te zwaaien de kokospalmen (vanwege hun 
groote hoogte) en krom worden (de sporen) der hanen, dan zullen we elkaar weer ontmoeten en $\mathrm{u}$ weder noodigen tot ( $\mathrm{u}$ afwachten met) een offermaaltijd".

Dienzelfden nacht alle priesters (priesteressen), allemaal dansen ze (en doen dit) gedurende drie of vier nachten, nacht en dag. Wordt het licht na den derden of den vierden nacht op dien danstijd, dan zijn er ongeveer drie of vier priesters die kokosnoot-water gaan sprenkelen (om de schadelijke krachten onschadelijk te maken) in de verschillende huizen, vergezeld door niet-bezeten helpers ongeveer vijf of zes. Waarmee dan wordt besprenkeld, is het water van jonge kokosnoten. Met dat ze aankomen bij de verschillende huizen (van het dorp), nemen ze blaren van een dajow-heester en doopen die in het water van die kokosnoten en sprenkelen daarmee her- en derwaarts in de hoeken der huizen.

\section{ZANGEN IN DE TAAL VAN HET LANDSCHAP BOLAANG MONGONDOW.}

BONDIT IM BOLIAN.

1.

Bogani in toedoe im Bilalang:

Inami ${ }^{1}$ ) naa-don doman, ai-nolansik ko lengkoe'an ${ }^{2}$ ).

Oempai ing gina ai-mobawang,

norakoet ko rimoekoedan ${ }^{3}$ ),
ZANGEN VAN PRIESTERS (PRIESTERESSEN).

1.

(De geest genaamd) Voorvechter van den top van Bilalang (dorp in het distr. Pasi) zegt:

Ik ben hier ook al, (ik) heb al gedanst (gesprongen) op den weg.

Daar het hart al ruim is (prettig gestemd),

heb (ik) gebracht de geesten (der zieken),

1) Deze vorm beteekent eigenlijk: het onze (excl.), die van ons, en zou hier kunnen worden vertaald met: onze geesten, maar inami staat hier slechts voor kami of akoeoi: ik. In priesterzangen worden meermalen gewone woorden veranderd of vervangen door vreemde.

2) lengkoe', molengkoe': krom, van praten bijv., ook van een weg: bochtig; lengkoe'an: met bochten, het of de kromme, in priestertaal: weg (wat in gewone taal dalan is) en ziet dan vooral op de wijze van trommelen, want het geluid der trom is eigenlijk de weg waarop de bezeten priester danst, of liever: waarvan de geest zich bedient.

$\left.{ }^{3}\right)$ Deze zin luidt in gewone taal: nogakoet kon dimoekoed. (Tontemb. : nimoe'koer, ziel, geest). 
ai-noonggot, ai-nolalang.

Pokopandoi, pokotoekang!

Onoe dongka im ponangoian

lolaki mosalendangan?

Mopodet ${ }^{4}$ ) dee-deeman,

ilabotkoe, kinantangan

ko limanja kololanan, binibit ko impoejoean.

Nion-don im bangka' ginapang,

ileagan in sinomboelan.

Botoi-monag pogagolan kom pintad inta boelawan, kon toea-ta in tai ompoean.

Abitkoe ede' ing gajang, poeloenja poeloe boelawan; baja' ankoe posolalang motomboekoe, motompoelang ${ }^{5}$ ). (die) reeds lang, al heel lang (aan het zwerven waren).

Gedraag je verstandig, toon je knap!

Wat wel zal duidelijk maken dat je genoemd wordt

een sterke en dappere man (een held)?

Ziek is (de patient) niet (maar vrijwel hopeloos, ,ziek" is een veel te zachte term), (maar) ik heb hem tegengehouden, vastgegrepen

bij zijn rechterhand, hem gedragen aan (zijn) kruin (hoofdhaar, en zoo gered van den dood).

Daar zijn al de twee bijeenbehoorende prauwen, voorzien van zeilen die maan (sikkel) vormig zijn gemaakt.

Roei zuidwaarts om het snelst naar het strand dat van goud is, aldaar zijn zij die vereerd worden (goden).

Mijn wapen is het kleintje van een kris (zwaard),

het gevest ervan is een gouden handvat;

hiermee (met uitgetrokken zwaard) ga ik de verre reis ondernemen

(als) passend (voor mij, in overeenstemming met mijn waardigheid), goed.

4) mopodet is een priesterwoord voor motakit: ziek.

5) Dit woord is in gewone taal mopia: goed. Totoeoe motompoelang im pototomoe im posigadan: zeer goed is de wijze van ontvangen van deze menschen (pr. taal), d.w.z. ze hebben mij (de geest) met de noodige eer ontvangen, en de bonditzang van den priester is op schoone wijze meegezongen; monenden: zingend herhalen van een bondit-zangregel. 
2.

Ki mobata', ki Oensi' on:

Kami, toele, naaia bidon,

a kom boeloed, kom Pantowon.

Boki'koe $^{6}$ ) i mololingoe-don

kom boeloed norogintontong,

kong koeroi ing kajoe daagon,

kainia : „Ikow, inta-don,

ojoeon-pa i andoepon,

poesoeng-pa in taliibogon ${ }^{7}$ ),

potoroi ${ }^{8}$ ) bolibongkangon ${ }^{9}$ )."
2.

(De geest genaamd) de Schoone, Oensi'on (zegt):

Wij, vrienden, zijn weer hier, (wij die)

steeds verblijven op den berg, op den Pantowon (hoogste berg in het land der geesten).

Mijn helpster heeft (mij) bijna vergeten

op de bergen die tegenover elkaar liggen,

op den top van den daagonboom,

zij zei: „Jij moet maar gaan, (want)

er is nog iets waarvoor (ik) ergens moet aangaan,

ik wil eerst de bloesems hebben van de taliibogon-plant (die begeerte wekt),

waarmee men doet watertanden zeer overvloedig."

6) Dit van Ternate stammende woord betekent eigenlijk: gemalin van den vorst, maar wordt hier gebruikt voor: helpster(s) der priesteres.

7) ibog: wensch, begeerte, ook: het water dat iemand in den mond komt bij het zien van iets lekkers bijv. of bij een ziekelijke aandoening der maag (hartwater); het voorv. tali- heeft meermalen een vluchtig-makende beteekenis, terwijl -on bij sommige woorden te kennen geeft: behept met wat het grondw. zegt, aangetast worden door wat het grondw. noemt; taliibogon is dus weer te geven met: waardoor de begeerte even wordt gewekt, die het water even in den mond doet komen. Hier is vooral bedoeld: door de aanwending van de bloesems van de taliibogon zal de ingevaren geest „als gesmeerd” kunnen spreken.

8) toroi (tojoi), toemoroi: druppelsgewijze uitlekken; potoroi: waarmee men zoo'n uitlekkerij veroorzaakt, wat hier dan is vertaald met: waarmee men doet watertanden.

9) bongkang, mobongkang: met een vaartje iets overgieten, zoodat er het noodige wordt gemorst; het gebruik van boli- hangt veelal samen met een beweging en kan hier ook wel frequentatieve beteekenis worden toegekend: bolibongkangon is dus te vertalen met: het zal zeer overvloedig en vrij langdurig stroomen. 
3.

Ia, io, ai-motakod,

simpotoi mopolom-polok.

Ko landakan bo toemongkod,

bogani a mokidongog

ko joea-joeak i logantod ${ }^{10}$ ).

\section{4}

Bela Manoengkararit:

Akoeoi nongko o monik, akoeoi, toele, a pa mosilig,

si a pa maja' molansik

kon dimoekoed kinoemalig.

Nion-don im bangka' pinipid,

ileagan in tongo ikit.

Botoion tangki-tangkidit,

kon toedoe im boeja' in toebig;

botoion-don pongiomonik,

maja' kom boki' nopipid.

Oelatēā riminsi-rinsik.
3.

$\mathrm{O}$, o, (ik) wil al beginnen met bergbeklimmen (terugkeeren), het verhaal zal (dus) kort worden.

Op een vlakte der berghelling zal ik stilhouden, de voorvechter zal luisteren te midden van de logantodzangen.

4.

(De geest) Bela Manoengkararit (zegt):

Ik kom van boven, $i k$, vrienden, wensch eerst af te dalen (van den berg),

want ik wensch eerst te gaan dansen

voor de geesten die wild (schuw) zijn geworden.

Daar zijn al de op een rij geplaatste prauwen,

voorzien van zeilen die uit èèn lapje bestaan.

$\mathrm{Ze}$ moeten worden geroeid steeds dicht langs het strand, boven op het schuim van het water;

roei haar dan koersend naar het noorden,

ga naar de op een rij geschaarde helpsters.

Het zweet (der roeiers) druppelt gestadig.

10) Als een prièster(es) zoogenaamd is flauwgevallen, omdat iemand een verboden woord bezigde, ofwel omdat bijv. een kind tusschen hem en den tamboer doorging, dan wordt deze weer bijgebracht met een logantod-zang (door een oude te zingen). Dit laatste wordt genoemd: logantodain. 
5.

Ki Mando Motombogani $\left.{ }^{11}\right)$ :

Toele, naa-don ing kami.

A kotantoe-tantoe'-nami,

minaja'-bi' kinoeani.

Lagi boeian ing kami,

ogoi-ai doman im ponoendi ${ }^{12}$ ), diaan pobaloen-nami.

6.

Ki Mando Mosalendangan:

Akoeoi naa-don doman.

Kinoeani im posigadan ${ }^{13}$ ),

inta-ka maja' ontongan.

Koonagan ing ko landakan,

boerangin nogilitoe'an.

Ilabotēā, kinantangan

ko limakoe kololanan, pinongaloi, pinolampang.

Binoetaran in tengkelan ${ }^{\mathbf{1 4}}$ ),

5.

(De geest genaamd) Mando die doet ais een voorvechter (zegt) : Vrienden, hier zijn we al.

(Hoewel we) steeds in onze vaste plaats verblijven, zijn (we) toch gegaan (daar we) werden geroepen.

Spoedig is het tijd waarop we terugkeeren, geef ons toch sigaretten, breng onze teerkost.

6.

(De geest genaamd) de sterke en dappere Mando (zegt):

Ik ben hier ook al.

(Toen ik) geroepen werd door de menschen,

(zei ik) : komaan, laat ik er maar naar gaan zien.

Naar beneden komende bij de vlakte op de berghelling, zaten (daar) de priesters bij elkaar.

(Ik) werd door hem tegengehouden, vastgegrepen

bij mijn rechterhand, daarmee heeft hij mij geroeid (geleid),

heengevoerd (doen stappen over hindernissen).

(Ik) ben begoten met kokosnootwater,

11) bogani: voorvechter; motombogani: zich gedragen als een voorvechter, dit willen worden. Een met to- afgeleid grondwoord zegt veelal: zooiets als het grondw.

12) ponoendi is een priesterwoord voor gau: sigaret.

13) Priesterwoord voor: intau: menschen.

14) Priesterwoord voor jonge kokosnoot en het water ervan. Tengkel, monengkel beteekent in het gewone leven: handen in de zij zetten, op de heup dragen. 
inami noïntoi doman.

Polom-polokon i ooeman,

mobajong-pa ing kosoesaan.

$$
7 .
$$

Bogani ki Kaoempoengan:

Kami, toele, naaia-don doman, toemakoi toemonggoloean

kom bangka' sinakoian, ileagan in sinomboelan,

kon doellakēā ing kilang-kilang.

Botoi-monag pogagolan, poliboe kon toeboean, toeboe kom pintad boelawan. Molansik-pa tokomintan, kodoea, kotoloe baloeian.

Talanja ${ }^{15}$ ) pojosingogan.

8.

Ki Mongiloi $\left.{ }^{16}\right)$, ki Mongilag $\left.{ }^{17}\right)$ :

Akoeoi nongko o moentag, nongkon simpoenoe'on in dagat, (dit) had ik ook begeerd.

(Ik) zal maar kortmaken het verhaal,

(want) veel nog is (mijn) werk.

\section{7.}

(De geest genaamd) de Voorvechter Kaoempoengan (zegt) : $\mathrm{Ik}$, vrienden, ben ook al hier. (Ik) bestijg - me in de plaats stellende van een ander de prauw die bestegen is, voorzien van een zeil dat maan(sikkel)vormig is gemaakt, op den voorsteven is het klingelende versiersel.

Roei zuidwaarts om het snelst, rondom de aanlegplaats, leg aan bij het gouden strand.

Dans nog ieder één keer, tweemaal, driemaal veranderend van zang.

(Wat ik nu heb gezegd) zal misschien wel voldoende zijn om er met elkaar over te praten.

8.

(De geest genaamd) de Inspecteur, de Onderzoeker (zegt):

Ik kom uit het westen, van de uiterste grens der zee (waar deze de kim raakt),

\footnotetext{
15) talanja: zoo ongeveer voldoende, nauwelijks toereikend. Kaanon naa talanja ponogoejoton: deze (voorraad) eten zal misschien voldoende zijn om de krachten te onderhouden (maar meer ook niet, vet zullen we er niet van worden).

16) mongiloi: onderzoekend bekijken, inspecteeren, ook zijn eigen kleeding bijv. met naar beneden gerichten blik of naar beneden gebogen hoofd; imiloi: het hoofd laten hangen; noïloi-don i oeloenja: neergebogen was zijn hoofd.

$\left.{ }^{17}\right)$ mongilag: onderzoeken wat iemand mankeert; ilag-ai-pa im ponto' naa, mongo onoe $i$ mokopodet: toe, onderzoek even dezen jongen wat of (hem) ziekmaakt.
} 
motoendoe' kon tolibag,

mamangoi modapa-dapat

kom boei' minta bo agat.

Inta-don, moboei-moentag.

Onoe-don bai norokiap?

Boejak ing kokiap.

Darag-mata! dagit-moentag!

Lolaki a-nokoalap, nokoagow kon sinotag ${ }^{18}$ ).

Paring-don im bangka' sindoelak,

ileagan in togogopat,

kon doelakēa i lenso dodap.

Botoi-moeik, botoi-moentag,

bandera kom posibotak;

inia ing ko joea-joeak.

Porotogoe'-don ${ }^{19}$ ) kon tolibag!

9.

Ki modatoe kong Konoan: om te onderwijzen de tolibagzangen,

(ik) kom een onderzoek instellen naar alle geslachten en afstammelingen.

Komaan, (ik) keer terug naar het westen.

Wat is het toch dat steeds weer schittert?

(dat zoo iets is alsof velen met de oogen hebben geknipt)

De bloesems van de oogleden.

Span al je krachten in! pak het westwaarts!

De man heeft kunnen vangen, heeft kunnen rooven de gekauwde pruim.

Geef de sindoelak-prauw een andere richting,

die voorzien is van zeilen, iedere (mast of iedere prauw) vier, op den voorsteven (wappert) de welriekende hoofddoek.

Roei oostwaarts, roei westwaarts,

de vlaggen (wapperen) aan weerszijden;

de zijne (de prauw van Mongiloi) is in het midden. Heft allen aan een tolibag-zang!

9.

(De geest genaamd) de regeerder te Konoan (verblijfplaats der goden) zegt :

18) totag, monotag: kauwen, vooal van een pinangpruim; sinotag: het gekauwde, de geheel of gedeeltelijk uitgekauwde pruim. Als een bewijs van groote genegenheid nemen verliefde menschen wel elkaars pruimpje uit den mond en kauwen dit dan zelf verder. Op dit gebruik wordt in dezen zang gezinspeeld, en met sinotag wordt eigenlijk een vrouw bedoeld.

19) togoe $e^{\prime}$, motogoe $e^{\prime}$ : een zang inzetten; potogoe $e^{\prime}$ hef aan! porotogoe $e^{\prime}$ : heft allen aan! Het infix -or- heeft meervoudige of frequentatieve kracht.

D1. 104. 


\section{Akoeoi naa-don doman, kinoeani im posigadan.}

Boki'koe inta kojongan,

onda ing ki bila kojongan?

Naa bo ai-molansikan.

Akoeoi mongoela doman kong kokaloi ${ }^{20}$ ) sinalempang, talempangon ko ogotan;

notajow ilo-iloian.

Boerow-ka-don in sinakoian,

ileagan in sinomboelan,

kon doelakēā ing kilang-kilang.

Botoi-monag pogagolan, toeboe kom pintad boelawan, kon totoeboean im bolian.

Porotogoe'-don ko ooeman, modali', modagol ${ }^{21}$ ) doman. Oempoeng, ki Bata' im boelan,
Ik ben hier ook al, (daar ik) geroepen werd door de menschen.

Mijn helpster die (me) altijd bijstaat,

waar zijn de oude vrienden (zij die gewoon zijn voor me te trommelen)?

$\mathrm{Nu}$ ga ik al dansen (al behept met de lust tot dansen).

Ik verzoek ook met aandrang om (twee) gekruiste doeken, bind ze kruiselings om (mijn) lenden;

het is mooi (fraai van kleur enz.) om er voortdurend naar te kijken.

Wend dan toch de prauw die bestegen is, voorzien van een zeil dat maan(sikkel)vormig gemaakt is, op den voorsteven is het klingelende versiersel.

Roei zuidwaarts om het snelst, leg aan bij het gouden strand, bij de aanlegplaats der priesters(essen).

Heft allen aan een zang (letterl. : verhaal), vlug, (maar) toch niet al te snel. De (kwade) geest (genaamd) : de schoonheid der maan,

\footnotetext{
20) kaloi, mongaloi: slingeren met armen bijv.; kokaloi: vin, waarmee de visch zich beweegt, hier: $\operatorname{doek}(\mathrm{en})$ van een priesteres, vooral die welke zij bij het dansen in de hand houdt en waarmee zij slingerende bewegingen ofwel roeibewegingen makt en die door haar dan ook wel bobotoikoe: mijn roeiriemen, worden genoemd; de-geest in haar makt nl. dan de reis per prauw.

21) modagol beteekent eigenlijk: hevig, in erge mate, maar schijnt steeds met de ontkenning dia $^{\prime}$ : niet, te worden gebruikt, zoodat - ook als deze eens wordt weggelaten, zooals hier het geval is, - modagol toch moet worden opgevat alsof er is gezegd : dia' modagol : niet al te...., niet erg.....
} 
sinalow $\mathrm{i}$ inangoian.

Modamal-don in toengkoelan.

Potogoe'-don ko ooeman!

10.

Ki Daëa, ki Tosimboi :

Toele, naa-don iakoeoi, tali-talib-bi' iakoeoi,

ilabotēā bo kinapoi,

bo ilimitoe' noboboi

bo notogoe' kon simpotoi.

Onda-don ing ki togi baloi?

Roemogi-te-don iakoeoi, bai n dongka moboei mangoi,

kotaki-takin i itoi.

11.

Ia, io, ki Keaton :

Akoeoi, toele, i naaia-don, nojangkom kong kijondom.

Doei' im boki'-naton, boki'koe sinontoelong.

Ponto'koe onda-don nion?

Ambe', ojoeon-pa i oelaon. is overwonnen door de bezeten priesteres (in wie is gekomen de geest).

(Ik word) erg op de proef gesteld (veel zijn de beproevingen, nl. door de vele vragen der aanwezigen)

Hef aan een zang!

10.

(De geest) Daëa, (de uitstrooier) Tosimboi (zegt) :

Vrienden, hier ben ik al, ik wou heusch ineens voorbijgaan,

(maar) ik werd door hem tegengehouden en uitgenoodigd, en (toen) ben ik gaan zitten in de rij (op een rij met anderen), en heb aangeheven een zang. Waar is toch de eigenaar van het huis?

Ik wind me al op (word al boos), (een anderen keer) zal ik wel terugkomen, tezamen met de oudere (geesten).

11.

Ja, ja, (de geest) Keaton (zegt) : $\mathrm{Ik}$, vrienden, ben nu al hier, in de hand houdende kijondombloemen.

Verhef onze helpster, mijn helpster die (ik) als een eenig kind (toelong) heb gemaakt.

Mijn jongen, waar toch is die nu?

Ach, er is nog iets waarom (ik) wil vragen. 
Moikow-don im pongontong,

dia'-don ing koanga'on:

kaleboe'koe ko modolom,

bobotoikoe noree'-don.

Ooeman tonga'-pa nion.

Sinakoiankoe i nion-don,

ileagan in togogonom.

Botoi-monag, ponginion, toeboe kom pintad doengkoelon. Inako' i na'-don nion, imonimoe potogoe'-don!

\section{2.}

Ia, io, Manoengkeat:

Akoeoi nongko o moentag, Inia, koema, in tolibag,

dodoei’ joemongka-jongkat.

Inta-ka-pa, a pa mamonag, mea $^{22}$ ) kom boki' nopapad, ponoendi tongo tatak.

Boki'koe modali' lalat, mongobodok, mongobatak.
Gijlieden, kijkt (zelf maar) wat mij ontbreekt,

er is niets meer dat prettig stemt (noodigt tot toeven) :

mijn sarong (is alleen maar te gebruiken) in het donker (zoo slecht is ze),

mijn ,roeiriemen” (doeken: kokaloi) zijn al slecht (leelijk). Het verhaal voorloopig tot zooverr.

De door mij bestegen prauw is al hier (daar),

voorzien van zeilen, iedere (mast) zes.

Roei zuidwaarts, ga hier langs, leg aan bij het eerste strand.

De mijne (mijn zang) zij hiermee voldoende, die van ulieden, hef die aan!

12.

Ja, ja, (de geest) Manoengkeat (zegt):

Ik (kom) van het westen.

(De zang) van hem, nietwaar, is een tolibag-zang,

een loflied steeds weer zacht ruischend.

Komaan dan maar, (ik) wensch eerst af te dalen,

ga naar de op een rij (gezeten) helpsters

(en vraag om) een sigaret, èèn stuk.

Mijn helpsters zijn zeer druk, allemaal dom, allemaal onbehouwen.

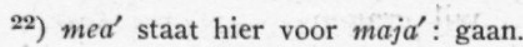


Nion-don im bangka' sindoelak, ileagan in togogopat,

kon doelakēā i lẹnso dodap,

bandera kom posibotak.

Botoi-moeik, botoi-moentag,

ponotoi im boeja' in dagat!

\section{3.}

Ki Keang-keangon-in-tompot ${ }^{23}$ )

Akoeoi nongkon Toemolog, a mosilig mogogitog.

Inta-don, mopokodapot,

dika-don toemongko-tongkod!

maja' mongoepang ${ }^{24}$ ) monotop.

Tonga'-pa nion i itog,

akoeoi lagi motakod.
Hier is al de sindoelak-prauw, voorzien van zeilen, iedere (mast) vier,

op den voorsteven een welriekende hoofddoek, vlaggen aan weerszijden.

Roei oostwaarts, roei westwaarts,

doe (haar) gaan over het schuim der zee!

13.

(De geest genaamd) ,de speelbal der winden" (de windgod?) (zegt) :

Ik (kom) van Toemolog, wensch den berg af te dalen om te spelen (dansen).

Komaan, zetten (we) de reis voort,

houdt niet meer herhaaldelijk stil!

(om te) gaan sirihpruimen (en) sigaretten te rooken (zuigen).

Tot zoover voorloopig het spel (de zang), ik moet spoedig den berg bestijgen (terugkeeren).

\footnotetext{
23) keang: een soort strik om kippen mee te vangen; kokeang: een speeltje, iets aan een touwtje, dat kinderen in den wind laten wapperen; in sommige plaatsen beteekent kokeang ook waaier (= kokeab); keang-keangon kan vertaald worden met: wat steeds door den wind wordt bewogen, wappert, maar het is ook mogelijk dat hiermee een plaats in het luchtruim wordt bedoeld (-on heeft ook plaatsaanduidende beteekenis) en ki Keang-kcangon zou dan een soort windgod kunnen zijn.

24) oepang, mongoepang, sirih pruimen; pongoepang: pruimbenoodigdheden. Deze woorden behooren tot de priestertaal.
} 


\section{TOLIBAG ${ }^{1}$ ).}

1.

Tolibag i lolaki inta moboeat, maja' i mojajoe', tala'an ko i boeloinja.

1.

Aka ikow mokoboloi ${ }^{2}$ ), tala'ankoe tongo pajoi ${ }^{3}$ ).

Koangoian i mokokiangoi ${ }^{4}$ ), tonga' pomama'nja i ogoi,

dika limitoe' moboboi.

Kototaauan $^{5}$ ), iakoeoi mololiom ${ }^{6}$ ) ko oeatoi ;

balengkoeng goeli' ${ }^{7}$ ) ing gogoi.
1.

Lied van een man die vertrekt, een verre reis onderneemt, zijn vrouw achterlatend.

\section{1.}

Indien je het kunt uithouden, verlaat $\mathrm{ik}(\mathrm{je})$ een rijsttuinjaar. Als een gast komt, slechts sirihpruimbenoodigdheden die (mag je hem) geven, (je) mag niet naast (hem) gaan zitten.

Het is goed bekend, ik ben een slikker van ijzer (een ijzervreter, vechtersbaas); een kris stilt den honger (voor vechten laat ik mijn eten staan).

1) tolibag, vers, soort puntdicht, lied.

2) mokoboloi, kunnen uithouden; het voorv. moko- heeft hier de kracht van „kunnen”, zie $\S 58$ (Hier en verder beteekent $\S$ : paragraaf der spraakkunst van het Bolaang Mongondowsch, in Bijdr. Kon. Inst. v. T., L. en V., deel 85 en 86). mobolnoi, uithouder: momoloi, aanhoudend iets doen.

3) pajoi, rijst in den bolster, beteekent hier de tijdruimte vanaf het planten tot den afloop van den oogst, en is daarom vertaald met: rijsttuinjaar.

4) mokokiangoi, (angoi: komen) moki- duidt vaak aan: verzoeken, vragen om wat het grondw. zegt, of: verzoeken te doen wat het grondw. te kennen geeft; mokoki- (geredupliceerd moki-) zegt: herhaaldelijk verzoeken te...... ; mokokiangoi, dien men gewoon is uit te noodigen om te komen, gast. § 77 .

5) kototaauan, het is voldoende of goed bekend; ook hier versterkt de reduplicatie van het grondw. taau de beteekenis. Zie $\$ 221$, laatste gedeelte.

6) mololiom: mo- + geredupl. gr. w. vormt ,beroepsnamen”, gewoon zijn te...., ook: nu eenmaal onderhevig aan....; moliom, slikken; mololiom, slikker, heeft hier overdrachtelijke beteekenis: vrees niet voor bloedstorten en dood, ben voor niets bang.

7) goeli', ook: oeli': in orde of in den oorspronkelijken toestand brengen, ook stillen van honger en dorst, van 't verlangen naar iets of iemand; mogoeli'-pa $i$ jogang: eerst lesschen de dorst; mogoeli'-pa in tanob: eerst stillen het verlangen. 
2.

Aka ikow mokotahang ${ }^{8}$ ), tala'ankoe tongo boelan.

Koangoian i mongongimbaloian ${ }^{9}$ ) tonga' pomamánja i ogoian,

dika limitoe' mogapang ${ }^{10}$ ).

Akoeoi, kototaauan, mololiom kom boelawan;

balengkoeng goeli' i jogang.

2.

Tolibag in tajow-mobiag, moïgoem kong kirimang ${ }^{11}$ ) (padoeli) kon tongo pobiagēā mongodeaga.

1.

Lajoeg-don iikow limboekon, loemajoeg simido-sidong ${ }^{12}$ ),
2.

Indien je het kunt uithouden, verlaat ik je één maand.

- Als er een bezoeker komt, slechts sirihpruimbenoodigdheden mogen (hem) gegeven worden,

(je) mag niet dicht bij (hem) gaan zitten.

$\mathrm{Ik}$, het is goed bekend, ben gewoon goud te slikken (sta voor niets);

een kris stilt (mijn) dorst.

2.

Lied van een jongeman (die) verzoekt om een cadeautje aan een meisje van zijn leeftijd.

1.

Vlieg uit gij wilde duif, vlieg zeer snel,

8) mokotahang, in betcekenis gelijk aan mokoboloi: kunnen uithouden; het Maleische „tahan” is hier al ingeburgerd.

9) mongongimbaloian (gr.w. baloi: huis) duidt iemand aan, die erg graag op bezoek gaat; het suffix -an beteekent hier: behept met de lust daartoe, en het geredupliceerde prefix geeft frequentie te kennen; mongimbaloian: huis-uit huis-in gaan, leegloopen, ook: op bezoek gaan; moïmbaloian: iemand, die nu eenmaal de gewoonte heeft steeds op bezoek te gaan. Voor den voorslag $i$-, die secundaire grondwoorden vormt, zie $\$ 89$.

10) gapang, zij, kant, rij; kong gapangēa : aan zijn zij.

11) kirimang en padoeli zijn aan het Maleisch ontleende woorden, beteekenen beide geschenk (gezonden geschenk).

12) simido-sidong, zich zeer snel voortbewegen, maar men ziet bijna geen vleugelslag; simidong: vanuit de hoogte ineens neerschieten op een prooi, zich daarop werpen (van een roofvogel); sidongan: jongensspeelgoed, bestaande uit een stukje kokosdop, bevestigd op een houten staafje, dat men door aan een hierom gewonden touwtje te trekken, in een bamboe-kokertje snel kan laten draaien. Voor infix -im- zie $\$ 178$.

${ }^{13}$ ) tampalioe is w.s. gevormd van lioe: over (de grens), voorbij (het gevaar), te bovengaand, maar bij andere woorden heb ik het samengesteld prefix tampanog niet aangetroffen; mocht tampa- echter een oudere vorm zijn van tompo(to- + genasaleerd po-), dan zou tampalioc te vertalen zijn met: maakt dat het passeert de...... toemampalioe : zorg dat je heenkomt over, zonder ongelukken passeert (de hindernissen). 
toemampalioe ${ }^{13}$ ) ko ambong ${ }^{14}$ ).

Moïonag-mangoi in Tobongon, dia' panga' bo libo'on

i nai ${ }^{15}$ ) tete', i nai lansong ${ }^{16}$ ),

salamkoe im pogoemanmoe-don.

Kinodaitan-don in totopon;

dongka tabakoe' bo silon

pokidia-mai motorong,

boetoelon ko alimomon ${ }^{17}$ ),

pokibibit-mai kong golom,

kon tolatan ${ }^{18}$ ) dolo-dolom.

3.

Tolibag i mongodeaga kon tajowmobiag, moïgoem kom padoeli (kirimang).

Koina $^{19}$ ), moboena-boenanang ${ }^{20}$ ), inonagkoe i langagan (vlieg) heen over de hindernissen.

Als (je) aankomt te Tobongon,

- en 't wellicht niet uitblijft dat wordt gevraagd (naar mijn bedoeling)

door de moeders, door de tantes (vrouwen),

zeg jij dan dat ik (ze) groet.

$\mathrm{Al}$ op is hetgeen gezogen wordt (sigaretten);

slechts tabak en sirihkalk

laat die vlug brengen naar hier, knoop het in een alimomon-doek, laat het dragen naar hier op de wolken,

op den zuidenwind 's morgens vroeg.

3.

Lied van een jongedochter voor een jongeling, verzoekende om een presentje.

Zooeven, bij het lichtworden, ben ik naar beneden gegaan om te bekijken

14) ambong, dam, dijk; hier is bedoeld: ambong ing giman, een soort hindernis tusschen strikken voor boschkippen of vogels, om ze zoo gemakkelijker in den strik te krijgen.

15) nai duidt aan dat de door het volgend woord genoemden bij elkaar behooren, het is een verkorting van naja, wat weer een vorm is van het oneigenlijke pers. v.n.w. taja (zie § 236).

16) lansong is een vrouwelijke eigennaam, maar wordt ook gebruikt in zangen als aanspreekwoord voor vrouwen, wat dan weer te geven is met ons „dames”. Ik heb het hier - een weinig vrij - met tantes vertaald.

17) alimomon, een zijden, langwerpige doek, die als versiering over den schouder of op het hoofd wordt gedragen.

18) tolatan, het Maleische selatan, voor zuidenwind.

19) De vier eerste regels van dit vers willen te kennen geven: uitziende, zooals gebruikelijk is, naar de leden der andere kunne, en: ik ben in de opgewektheid der jeugd.

$\left.{ }^{20}\right)$ moboena-boenanang, zoo omstreeks het aanbreken van den dag; boenanang: dageraad (we meenen hier met het infix -oen- te doen te hebben, $\S 183$ ); moboenanang, aanbreken van den dag. 
ki toendi, ki kotoloean,

lokoetoi mogalilian ${ }^{21}$ ).

Noïgara'-mai ${ }^{22}$ ) ing ki Dajan,

lolaki mosalendangan, nonongkiki ${ }^{23}$ ) kom bobodan.

Ilabotkoe kinantangan

ko limanja kololanan,

bo inoeni pinolibóan

mongo kajoe onoe in totokan ${ }^{24}$ ).

Kajoe dondo' sinojangkang ${ }^{25}$ ).

Akoeoi, oele, im ponombiagan ${ }^{26}$ )

kon doedoek bo tojomboeian, de sterren, den gordel van Orion,

de elkaar voorbijdrijvende wolken.

Toen kwam plotseling Dajan in mijn gedachten,

een sterke en dappere man, over den schouder hangende een bamboe met lijmstokjes.

Ik heb hem tegengehouden, bij de hand gevat,

bij zijn rechterhand, (d.w.z. zijn verzoek ontvangen)

en onderzocht door er naar te vragen,

in welken boom wellicht (hij zijn) lijmstokjes zou steken.

(Hij zei : in) een voor het grootste deel van zijn takken ontdanen dondo'-boom.

Ik (zei:) vriend, bewaar voor mij in het leven

een doedoek- en een tojomboeian-vogel,

21) mogalilian, elkaar voorbij drijven, vliegen (van wolken; vogels). Voor $m o(g)$ - $a n$, zie $\$ 39$ en 49.

$\left.{ }^{22}\right)$ noĭgara', kwam plotseling in de gedachten, kreeg (ik) het verlangen naar....; gara ${ }^{\prime}$ : begeerte, verlangen naar de andere kunne. Voor nŏ- zie § 90.

23) nonongkiki, iets aan een riem of touw over den schouder hebben gehangen en zoo dragen; tongkiki, gr.w., is ook ml. eigennaam.

$\left.{ }^{24}\right)$ totok, monotok, vogels vangen met lijmstokjes; totokan, waarin men zulke lijmstokjes steekt.

25) jangkang, bladerloos, zoowel van staande als van omgehouwen boomen; ijoemangkang: heeft zichzelf ontbladerd (bij de wisseling van bladeren); monojangkang: een boom ontbladeren door de loof-takken er af te hakken (de dikkere twijgen kunnen dan later weer uitloopen); sinojangkang: een bladerloos gemaakte boom, waar vogels graag neerstrijken. Voor het samengestelde prefix sino- zie $\S 128$.

26) ponombiagan, persoon, voor wien men iets verzorgd, hier: in het leven laat; po-an kunnen ook beteekenen: plaats waar, tijd waarin...., § 36; voor to- en pono- zie $\S 126$ en 151 .

Met ,im ponombiagan kon doedoek bo....” wordt hier bedoeld: de vruchten van je arbeid, waarvan we zullen moeten leven, 
pomiaan boeoi bo tondan,

na'-don boeloi bo kantang.

4.

Tolibag i mongodeaga kon tajowmobiag, inta mopojogoegoet ${ }^{27}$ ) ko inia, mangalenja: ko lollaki inta koïbogēā.

1.

Lamboengkoe biningkatan ${ }^{28}$ ),

soetara sinalempang ${ }^{29}$ ),

sinaloei-pa i mogogoejang,

pinomia boeoi bo tondan

a pa adi' kong gogoendanan.

Maloena in dia' poloean.

A potomoe, a posiman

kon sope' bo sinakoian;

potoeboe-mai in tolatan. om die te maken tot een verlokking en belooning, zooals echtgenooten en verloofden (doen).

\section{4.}

Lied van een jongedochter voor een jongeling die met andere jonge mannen kampt om haar, d.w.z. voor den man die haar bevalt.

1.

Mijn kabaja is blauw gekleurd (heel mooi), (mijn eer, maagdelijkheid, is zeer kostbaar)

(draag) gekruiste zijden (selendangs),

nog gekocht door de ouders (grootouders),

gemaakt tot een verlokking en belooning,

toen (ik) nog een kind was in de wieg.

Dit is de reden dat zij niet kan worden geleend (ik laat niet met me spelen).

( $\mathrm{Ik}$ ben) steeds gereed te ontvangen, steeds afwachtende de $s o p e^{\prime}$-prauw en die waar (je) inzit (bruidegomsstoet) ;

de zuidenwind doe deze hier aankomen.

27) mopojogoegoet, met elkaar kampen om iets, of: iemand is de oorzaak dat anderen om haar vechten; oegoet, mogoegoet: trekken, sleepen, rukken, ontrukken. Voor mopojo- (door invoeging van $-o j$ - ontstaan uit mopo-), zie $\S 85$.

28) biningkatan, wat in blauwe verfstof is gedrenkt, daaruit is opgenomen (opgehaald); bingkat, neem het op, bijv. een mat.

$\left.{ }^{29}\right)$ sinalempang, gekruist, van het secundaire grondw. talempang: kruisen, wat is afgeleid van tempang; monempang: vleermuizen vangen met een net aan twee lange bamboes gebonden, die bij het dichtslaan elkaar kruisen, voor het infix $-a l$ - zie $\S 179$. 
Darag-mata! dika oekatan,

sin dagiton-magi' in tagoedang.

Lolaki mosalendangan, bogani pinonangoian, pinonisi' ${ }^{30}$ ) kon taboean.

2.

Lamboengkoe biloedjoe,

pinonondan-pa i lakikoe.

Maloena in dia' poloeankoe.

A posiman, a potomoe

kon sope' bo djoeloen-djoeloe.

5.

Tolibag i mongodeaga, ponontot ${ }^{31}$ ) kon tajowmobiag, inta dia' $^{\prime}$ mokobali' monangag ${ }^{32}$ ).
Span al je krachten in!, laat me niet los, want dan word ik gegrepen door een krokodil (door een anderen man die me niet bevalt).

Dappere en sterke man, beroemde voorvechter, waarmee (anderen) zijn weggedrongen van familiegronden.

\section{2.}

Mijn kabaja is fluweel, (mijn eer, maagdelijkheid, is zeer kostbaar),

waarmee nog heeft beloond mijn grootvader.

Dit is de reden dat ik haar niet uitleen.

(Ik ben) steeds afwachtende, steeds gereed te ontvangen de sopé-prauw en de djoeloendjoeloe-prauw (den bruidegomsstoet).

\section{5.}

Lied van een meisje, waarmee (ze) beschaamd maakt een jongen man, die het niet aandurft (haar) te schaken.

30) pinonisi', waarmee men anderen heeft weggedrongen, er uitgewerkt heeft ; mosisi': nauw, krap, benauwd; monisi', benauwen, vernauwen, verdringen. Voor po- bij geredupliceerd gr.w., zie $\$ 213$.

De inhoud van dit vers wil te kennen geven: ik ben je genegen, maar ik ben een fatsoenlijk meisje en wil dus in alle eer en deugd met je trouwen; ik ben het waard dat je om mij kampt.

31) tontot, monontot, bang, beschaamd, verlegen maken; ponontot: waarmee men beschaamd maakt.

32) tangag, monangag, schaken, ontvoeren van een meisje, ook: in den bek wegdragen van het geroofde (door een hond bijv.). Voor het ontvoeren van een getrouwde vrouw wordt mongagow: rooven, gebruikt, 
1.

Onda-don nion doeajow,

bogani dinajo-dajow?

Nion mamagi'-mamakow

kon siga-sigad i linow.

Ora! dia' nokoagow

kon toja' kom bonoe i linow,

ko ngara ${ }^{33}$ ) im batoe moloenow.

2.

Onda-don nion toka-tokakak?

Nion mamoeik-mamoentag

kon siga-sigad in dagat.

Ora! dia' nokoalap

kon toja' kom bonoe in dagat,

ko ngara im batoe moloenat.

6.

Tolibag i mongodeaga kon tajow-mobiag inta dia' motoedoen mongantang ko inia.

Dona'-ai-don ing kami patoeng sinibat dia' notoedoen,
1.

Waar is nu de reiger (hij die vroeger steeds kwam en nu ineens wegblijft),

de beroemde voorvechter?

$\mathrm{Nu}$ loopt (hij) heen en weer tusschen de plassen (meertjes). Bah! (hij) heeft niet durven rooven

de visch in de plassen (uit het huis der ouders),

uit de opening tusschen de groene steenen (uit het huis der ouders).

\section{2.}

Waar is nu de toka-tokakakvogel?

$\mathrm{Nu}$ loopt (hij) oostwaarts en westwaarts

tusschen de zeeën.

Bah! (hij) heeft niet durven vangen

de visch in de zee, (uit het huis der ouders),

uit de opening tusschen de schoone steenen (uit het huis der ouders).

6.

Lied van een meisje voor een jongeling, die niet houdt (zijn belofte) zich te verloven met haar.

Laat het dan maar zoo zijn dat wij (zijn als) water-bamboe's, (die) een houw hebben gekregen (maar waarbij het omhakken) niet doorgezet is,

33) ngara, deurgat, opening tusschen iets. 
daoenē dongka i nogoeloeng.

Ibarat ${ }^{34}$ ) ngangoi ${ }^{35}$ ), ibarat bangkoeng ${ }^{36}$ ).

Dongka moikow im pokampoeng, porame takin ginaloem.

7.

Tolibag im bobai ko lolaki, inta dia' notoedoen noboeloi ko inia.

1.

Onda-don nion kakakoe,

oembo i lipoe' mobagoe?

Sindog-pa polibo'ankoe

pomoetoesan-pa ${ }^{37}$ ) ko ngakoe.

Nongonoe sim pinelemoe?

Akoeoi ${ }^{38}$ ) mangoi pongonoe? de bladeren ervan slechts die hebben bewogen (geschud). (Je woord) kan worden vergeleken met een stomp (mes), met een verroest ijzer.

Alleen jullie die moeten (maar) bij elkaar blijven, wees (maar) vroolijk met (je) familie.

\section{7.}

Lied van een vrouw voor een man, die niet heeft vervuld (zijn belofte) te trouwen met haar.

1.

Waar toch is nu de kakakoe-vogel (koekoek),

de oembo-vogel van het nieuwe dorp?

Blijf even staan (want) ik wil vragen

(of je) soms wilt verbreken de belofte.

Waarom is door je verhinderd (dat ik me met een ander verloofde)?

Wat zal er verder met mij gebeuren? (ik zal wel gauw sterven van hartzeer of zelfmoord plegen),

34) ibarat, zinspeling, bedoeling, gelijkenis, is overgenomen uit het Maleisch (Arab.), doch geheel ingeburgerd.

35) ngangoi, nongangoi, stomp, van mes, schaaf enz.

36) bangkoeng, oud, verroest hakmes, of een ander stuk verroest ijzer; nobangkoeng wordt ook gebruikt voor: stomp, d.w.z. in plaatsen waar nonga$n g o i$ minder gebruikelijk is.

$\left.{ }^{37}\right)$ pomoetoesan, hier is het Maleische poetoes: breken, als gr.w. genomen, hoewel een vorm van bontow van zuiverder taalgevoel zou getuigen.

38) Akoeoi mangoi pongonoe? si oemat dia' nogoeroe. Met deze woorden zie de vertaling - vernedert het meisje zich schijnbaar, maar in werkelijkheid is ze hier zeer scherp, want er wordt tevens mee bedoeld dat de jongeman ook te ouders beleedigd heeft, wat veel erger is, mangoi geeft hier aan akoeoi een 
si oemat ${ }^{39}$ ) dia' nogoeroe.

Koagi'an in djandjimoe, koedjoerat ${ }^{40}$ ) taba' i ompoe,

ikow-don in simingkolanoe ${ }^{41}$ )

momateha kong koeboerkoe;

boere'-ai i minja bondoe,

mobasa kon tangkabiroe $\left.{ }^{42}\right)$.

\section{2.}

Oempaka na' kami naa,

dia' gampang, dia' gila,

bo mamakow soematenga

bo goemoeman ${ }^{43}$ ) kon tangoinja. want ik heb niets geleerd (ben dom).

Wanneer je stervensuur komt, de oproep van de bode van den vorst (des doods), dan zul jij het zijn die zich inspant om het nog te halen (uit te voeren)

bloemen te strooien op mijn graf ;

besprenkel het met welriekende olie,

lees wat een overledene wordt voorgezegd.

2.

Hoewel (slechts menschen) zooals wij (hoewel we slechts eenvoudige menschen zijn), (we zijn toch) niet zoo gemakkelijk (te bedotten), zijn niet gek,

en gaan ons niet als een halfonwijze aanstellen

en zelf zeggen waar het om gaat (zelf zeggen te willen trouwen, zichzelf aanbieden).

ruimere beteekenis: als ik het nu alleen maar was! Met de volgende regels wordt te kennen gegeven: eerst op het eind van je leven zul je tot inkeer komen en begrijpen wat ik waard ben geweest.

39) oemat is hier vertaald met: ik, maar kan ook worden weergegeven met: ik behoor tot de menschen (die dom zijn), want oemat beteekent hier veelal: menschen, volk.

40) koedjoerat, ook gehoord als koedoeorat, is het Arab. kodrat; macht, almacht, hier vertaald met: oproep.

41) simingkolanoe, zich inspannen om het nog te halen, om nog tijdig te zijn, gr.w. lanoe. Voor het samengestelde prefix singko-, zie $\S 164$ en voor - im- $\$ 178$ en voor simi- $\S 163$. Zoowel si- als -im- hebben reflexieve kracht.

42) tangkabiroe is evenals tarakin, een verbastering van het Arab. talkin; mobasa kon tangkabiroe: lezen (voorzeggen) wat een overledene in het graf moet antwoorden, als hij ondervraagd wordt door de grafengelen.

43) goemoeman, zelf aanzoek doen (van een meisje), gr.w. goeman; mogoeman : aanzoek doen om een meisje; goemoeman kan ook beteekenen: zich bekend maken, zelf zeggen wie men is; ginoemoeman: hebben gezegd wie men is. 
Oemat motongkai, kita inoekat ko moestaka, kon dondangan ${ }^{44}$ ) in salaka.

Ki Ompoe ki togi mia.

\section{3.}

Oempaka na' kami doman,

dia' gila, dia' gampang,

bo mamakow bo goemoeman.

Oemat motongkai doman inoekat kon tosimbangan, kon tombibit bo batoean.

8.

Tolibag siri' i mongodeaga kohongian kon tajow-mobiag toeangi-lipoe' (simpal).

1.

Ki singgai ai-mooetoe, noliau-bi'-makow ing ginakoe;

kinotaliban-mai kamoemoe ${ }^{45}$ ), noreau-makow im bondoe.
De menschen zijn gelijk, wij zijn geplaatst op een weegschaal, waar duidelijk wordt het zilver (het onechte en het echte blijkt). De Heer is het die alles heeft gemakkt.

\section{3.}

Hoewel ook slechts menschen als wij zijn, (we zijn) niet gek, niet zoo gemakkelijk (beet te nemen), (we) gaan (niet) zelf zeggen (te willen trouwen).

De menschen zijn toch gelijkelijk geplaatst op de weegschaal, aan het handvat (touw der weegschaal) en waarop de gewichten worden geplaatst) of: op de weegschaal en balans).

\section{8.}

Spotlied van een meisje uit den aanzienlijken stand voor een jongeling uit de vrije burgers (simpal-stand).

1.

De zon was bijna in het zenith, waarlijk geheel in de war was mijn hart;

toen voorbij kwam de schoongekleede,

verspreidde zich rondom een welriekende geur.

\footnotetext{
44) dondang, stellen vóór , tegenover, en dan wordt duidelijk wie de meeste of wat het echte is; dondangan, waar dit gebeurt, waar blijkt wat echt (zilver) is, smeltkroes, soort toetssteen, maar w.s. is hier bedoeld: voor den Alwetende.

45) kamoemoe, mooie stof of goed, ook als eigennaam gebruikt.
} 
Mana-mai-koe i intau totoeoe,

intau-bi' nosopoe-sopoe ${ }^{46}$ ),

nobotak ki ata in datoe.

\section{2.}

Ki singgai ai-moonag, matakoe ing ginansiroi-moentag;

paramata i nooelindap,

noreau-makow in totad.

Mana-mai-koe i intau motoegat,

intau-bi' nobota-botak,

sinoemangoi ata bo rotag.

9.

Tolibag i lolaki kom bobai inta nobaloe, pinomaja' ko mongodeaga inta kinopatoian i kantangea.

$\mathrm{Ki}$ ine $\mathrm{i}$ motobog toea?

Ki abo' i Dadentoela, mokojoi kong kolimbonga, boetoelon bo pokidia

46) sopoe, pl. Maleisch, vergulden.
Ik dacht dat hij een echt (voornaam) mensch was (dat hij werkelijk was wat hij leek), (terwijl hij) warempel slechts een opgedirkt iemand was, voortgekomen (uit een geslacht van) slaven van den vorst,

\section{2.}

De zon was al aan het dalen, toen ik mijn oogen ophief en westwaarts draaide

en zag een edelsteen die het licht weerkaatste,

en zich de geur verspreidde van fijngemaakte welriekende bloemen.

Ik dacht dat hij werkelijk was (wat zijn kleeding deed vermoeden),

en hij was slechts een minderwaardig iemand (met veel ontsieringen, barstjes),

die zich zelf deed kennen als een slaaf en onbehouwen iemand (ongelikte beer).

\section{9.}

Lied van een man voor een vrouw die weduwe is, of voor een meisje dat getroffen is door den dood van haar verloofde.

Wie is het die daar trommelt?

De jonker Dadentoela, (hij) snijdt stukjes kalmus, die in een doek worden geknoopt en die (hij) laat brengen 
kon tangkili' taja lima.

Moïonik-mai i landakanēā,

mogogai mogogimpia ${ }^{47}$ )

moboeka' kon sinompaloma.

Nolangag-monik kom poja

dongka mopoeloe' bo lima,

tobatoe'-pa i agatē.

Kapite', dika moondok kopoetolan in totoekod; oempaka oentagon in tolog, lolaki nosindo-sindog ${ }^{48}$ )

mopobenteng im bosiot.

10.

Tolibag im bobai inta nobaloe.

1.

Sisingkoe baralojang ${ }^{49}$ ),

kede' im paramata intang, sopoenja sopoe boelawan;

sinaloei-pa i mogogoejang, door dienaren vijf in aantal.

Met dat (zij) aankomen op een vlak gedeelte van de berghelling, rusten (zij) behagelijk

en openen de duifvormig gemaakte rijstzakjes.

(Toen ik) naar beven keek naar de droge (rijpe) kokosnoten, waren er slechts vijftien (7 paren +1$)$,

nog één die restte er (had geen makker, nl. de weduwe). Kapitein, wees niet bang dat komt te breken de stut;

al komt rivierafwaarts een watervloed (moeite en verdriet), vele mannen staan gereed een benteng te vormen (om u) met (hun) kuiten (door deze dicht aaneen te sluiten).

\section{0.}

Lied van een vrouw die weduwe is.

1.

Mijn ring is als een in tweeën gespleten rotan (één kant plat), (bezet met) een kleine diamant, zijn verguldsel is gouden verguldsel ; nog gekocht door de ouders (grootouders),

47) mogogimpia, gr.w. pia, secundaire stam impia, goed opletten of men geen onheilspellende teekens ziet of hoort onderweg, gebruikt in den zin van ons: goede reis! Hier meenden we het te mogen vertalen met: behagelijk.

48) nosindo-sindog, gr.w. sindog, de herhaling duidt hier aan dat de handeling door meerdere personen wordt verricht; dezelfde vorm kan ook beteekenen dat de handeling aanhoudend of herhaaldelijk wordt verricht.

${ }^{49}$ ) baralojang, soort ring, in vorm gelijk aan een gladden trouwring, dus één kant plat, gelijk een in tweeën gespleten rotan.

D1. 104 . 
pinomia boeoi bo tondan,

adi'-pa kong gogoendanan.

Iloetoedkoe kon tondoïsikan ${ }^{50}$ ),

tondoisik i lima kololanan.

Pinongaloikoe ${ }^{51}$ ) bo nogopang ${ }^{52}$ ),

sinoemojop ${ }^{53}$ ) takin boelan.

Dia'-don im pononggoloean ${ }^{54}$ ) kom boeloi patiri ${ }^{55}$ ) im badan,

boeloi-pa nongko mongoadi'an,

oemoer nototabian. gemaakt tot een verlokking en belooning,

(toen ik) nog een kind in de wieg was.

Ik heb hem gestoken aan (mijn) pink,

aan den pink van de rechterhand.

Ik heb ermee geslingerd en (hij is) gebroken (nl. de ring), ondergegaan met de maan.

Niet meer is er een vervanger voor den echtgenoot (waarmee ik me) geheel één gevoelde, nog de echtgenoot vanaf de kindsheid (de ouders hadden ons als kinderen reeds voor elkaar bestemd), steeds hebben (we) elkaar lief gehad.

2.

Sisingkoe paramata,

sopoenja komintan salaka;
2.

Mijn ring is (een ring met) een edelsteen, zijn bekleedsel is geheel zilver;

50) tondoïsik en tondorsikan worden beide gebruikt voor pink.

51) kaloi, mongaloi, slingeren met armen, ook: roeibewegingen maken; kokaloi: zijvin van een visch, ook: de twee doeken, die een priesteres in functie in de handen houdt en waarmee ze z.g. roeit en die ze dan ook bobotoikoe: mijn riemen, noemt; pongaloi: waarmee wordt geroeid, geslingerd, ook: slinger het weg! pinongaloi: waarmee dit is gedaan. Voor po-, zie $\S 33$.

52) nogopang, gebroken (van ring, armband) ook: overleden (van voornamen), gr.w. gopang, soms als goang gehoord.

53) sinoemojop, gr.w. tojop, ondergegaan van zon, maan. Voor 't dubbel infix -inoem-, zie $\$ 175$.

54) pononggoloean, waarmee men vervangt, vervanger; loean: vervangen, verwisselen, leenen; tonggoloean: wat als vervanger dienst doet, wat een overledene vervangt, nl. slaapmat of bed, kleeren en pinangdoos, die te pronk blijven staan tot het doodenfeest is gevierd, tenżij dit nog heel lang duurt; mononggoloean: de tonggoloean in orde maken, ook: iemand voor goed (of langen tijd) vervangen. Tonggo- duidt op een langdurige of intensieve handeling, zie $\S 157$.

$\left.{ }^{55}\right)$ patiri, momatiri, soldeeren; mojopatiri: aan elkaar hechten door soldeer, lijm, met elkaar verbonden, aan elkaar gehecht; patiri im badan: gesoldeerd de lichamen, duidt hier een innige verbondenheid aan. 
sinaloei-pa ing goejangēā, sising-pa i baai-monia.

tonđan-pa pinonompia

ko(i) adi' bo ko(i) ompoenja. Iloetoedkoe kon talimondo' i lima.

Pinongaloi bo noroesa;

ginama'-bi' i togi mia.

Onoeonkoe-bi' naonda?

Dongka momolingkajang ${ }^{56}$ ) ko lima. nog gekocht door de ouders, nog een ring van hun grootmoeder, nog een belooning waarmee werden verblijd

de kinderen en de kleinkinderen. Ik heb hem gestoken aan den middelsten vinger van (mijn) hand.

$\mathrm{Er}$ is mee geslingerd en (hij is) gebroken (hier het Mal. roesak); (hij) is heusch weggenomen door Hem die alles heeft gemaakt.

Wat zal ik toch beginnen (doen)?

Slechts de handen op de rugzijde keeren (d.w.z. het aanvaarden, het op de geopende handen in ontvangst nemen).

Iedere regel van bovenvermelde liederen kan worden besloten met een der volgende uithalen:

$$
\begin{aligned}
& \text { odenon of : alai odenon, } \\
& \text { of : odenon da' dona'-ai-don, } \\
& \text { of : jojoi. }
\end{aligned}
$$

56) momolingkajang, secundair gr.w. bolingkajang: leg, keer het op de rugzijde; kajang: lenden, rugvlakte van iemand of iets, ondervlakte; boli- heeft hier de beteekenis van wenden, keeren, zie $\S 168$. Als iemand iets overkomt waaraan nu eenmaal niets te veranderen is, wat men heeft te aanvaarden als van Hooger hand ons toekomend, dan is de uitdrukking ,dongka momolingkajang ko lima" geheel op haar plaats. 